\title{
The Impact of Corporate Governance on Compliance with the Disclosures Requirements of Conversion to IFRS: Evidence from Saudi Context
}

\author{
Noorah Alshayea \\ 1.Accounting Department, College of Economics and Administrative Sciences, Imam Mohammad Ibn Saud \\ Islamic University, Riyadh, Saudi Arabia \\ 2.Master Student in Accounting at Qassim University, Qassim, Saudi Arabia
}

\begin{abstract}
Purpose - The purpose of this study is to examine the impact of corporate governance attributes of the board of directors and audit committee on compliance with the disclosure requirements about the conversion to IFRS imposed by Capital Market Authority in Saudi Arabia.

Design/methodology/approach - The sample consists of 236 firm-year observations of Saudi non-financial listed companies during the period of 2015 and 2016. Using content analysis, the disclosure score is measured by a self-constructed disclosure checklist and employs Ordinary Least Square techniques to estimate the impact of corporate governance attributes on compliance with the disclosure requirements of conversion to IFRS.

Findings - The results indicate that the overall disclosure compliance is $72 \%$. Further, the number of board of directors and audit committee meetings, and international investors are positively associated with the level of compliance with disclosure requirements regarding the conversion to IFRS, while the proportion of board of directors independence and the industry type are negatively associated with the level of compliance with disclosure requirements regarding the conversion to IFRS.

Research limitations/implications - The study covers only non-financial listed companies in the period from 2015 to 2016 in the Saudi stock market. Further, this study focuses on only one disclosure mean, which is companies annual reports, without any consideration of other different means. Finally, the results of this study are subject to the limitations known about the content analysis approach, especially coding the items in the checklist.

Practical implications - The results should help the regulators, enforcement bodies, and investors in Saudi Arabia to the need for further improvement in the disclosure practices and enhance the effectiveness of corporate governance.

Originality/value - This study contributes by provides additional evidence about the impact of corporate governance attributes on mandatory disclosures, as the literature available on this topic is limited, especially pertaining to developing countries.
\end{abstract}

Keywords: IFRS, Disclosure, Corporate Governance, Board of directors, Audit committee.

DOI: $10.7176 /$ RJFA/12-18-06

Publication date:September $30^{\text {th }} 2021$

\section{Acknowledgements}

I would like to express my sincere thanks and appreciation to Professor. Ali Alnodel, whose expertise was invaluable, and for his supervision and guidance during this dissertation. Prof. Alnodel's insightful feedback gave me the opportunity to expand my knowledge and brought this work to a higher level.

\section{Introduction}

Disclosure about the conversion to IFRS during the pre-adoption stage is essential for a company because it affects the investors' perceptions and decisions. Schipper (2005) and Verriest et al. (2013) have recommended that regulators should provide more guidance on how to implement the new accounting rules to increase transparency and comparability. Therefore, some countries try to support the conversion process by issuing what is referred to as the transition guidance. For instance, the European Securities Regulatory Commission, Australia, and Finland issued recommended guidance and obliged companies to disclose the impact of conversion to IFRS before the adoption period. In the kingdom of Saudi Arabia (KSA), the Capital Market Authority (CMA) required non-financial listed companies to disclose the IFRS transition plan in annual reports of 2015 and 2016. Hence, the main objective of this study is to examine the impact of Corporate Governance (CG) characteristics of Board of Directors (BD) and Audit Committee (AC) on Compliance with the Disclosure requirements about Conversion to IFRS (CDC) as detailed in 2015 and 2016 annual reports of non-financial listed companies.

The association between the companies' CG attributes and disclosure is unclear, especially with respect to the disclosure of adoption of IFRS. It has been assumed that compliance with regulations and requirements reflects different aspects of a company's CG structure. One of these aspects is the effectiveness of the CG 
structure as a company's compliance demonstrates it's respect to regulations, awareness of the various stakeholders' rights, acceptance of obligations, and the discharge of its fiduciary duties and responsibilities to protect itself from sanctions and banalities (Brown et al., 2011).

The impact of CG attributes on disclosure in general, and the impact of these attributes on disclosure about IFRS adoption need further investigations, because of its possible effects on users' decisions and capital market function (Verriest et al., 2013). However, the literature about the impact of CG structure on IFRS adoption has some shortages. First, a significant part of the literature has focused on the impact of CG attributes on voluntary IFRS adoption (e.g., Bentwood \& Lee, 2012; Iatridis, 2012; Stent et al., 2013; Chen \& Rezaee, 2012; Verriest et al., 2013). Nevertheless, none of these research efforts have been directed towards issues concerning CDC, especially before the adoption period. Moreover, all those studies with similar interest to the present study have been carried out in developed countries such as Portugal (Lopes \& Viana, 2008), Australia (Kent \& Stewart, 2008), and Finland (Miihkinen, 2008). This study extends previous studies in as much as it seeks to bridge the gap that exists in terms of examining disclosure of IFRS adoption in developing countries.

Second, the results of research studies with similar interests are mixed. There are a number of studies have confirmed the impact of CG in aiding compliance with the IFRS (e.g., Chen \& Rezaee, 2012; Verriest et al., 2013). Other studies discussed the impact of CG on discloser (e.g., Aksu \& Espahbodi, 2016; Kent \& Stewart, 2008; Krismiaji, 2019). However, the results of these studies are mixed in terms of determining which of these CG attributes have a positive influence on corporate disclosure.

This study is of significant importance, as it is considered being a response to a well-motivated research pertaining to the conversion to IFRS. First, there are limited studies that have investigated the determinants of $\mathrm{CDC}$ in annual reports. Further, the few existed studies on this topic have examined the CDC only by analyzing disclosure (Lopes \& Viana, 2008), or the impact of company characteristics (Miihkinen, 2008) on the CDC. In these few studies, also the impact of the CG variables on CDC is rarely examined. Third, the need for more studies investigating the factors that influence mandatory disclosures by companies, especially in developing countries. Finally, in the KSA's context, this study will support the Saudi vision 2030 aiming at the development of the Saudi stock market and fostering economic openness in the country through enhancing information transparency and increasing investor confidence.

The rest of the paper is organized into seven section as follows; Section 2 provides the accounting regulatory authorities in KSA. Section 3 reviews the main studies concerning the influence of CG on mandatory disclosure in annual reports. The hypotheses development and research method are outlined in Sections 4 and 5, respectively. Section 6 presents the empirical results. Finally, Section 7 presents the conclusions, limitations, and highlights suggestions for future research.

\section{Accounting Regulatory Authorities in KSA}

Public corporations in KSA have operated since the mid-1930s. The increase in oil income in the 1970s led to hasten the economic expansion, arising in a number of large corporations and joint-stock banks. However, the stock trading formalized when the government charged the Saudi Arabian Monetary Agency (SAMA) in 1984 with the responsibility of developing, operating, regulating, and monitoring the market activities (SAMA, 2015). Subsequently, Capital Market Law resulted in an establishment of an organization called the Capital Market Authority (CMA) in 2003 under the Royal Decree No. (M/30). The CMA is "a government organization that has full independence on financial, legal, and administrative matters and has direct links with the Prime Minister" 1. Also, in order to further facilitate the securities exchanges, the Saudi Capital Market Law established a joint stock company called Tadawul in 2003, that is the only authorized entity which can perform the trading of securities in KSA. Another important regulatory body that is responsible for development and approval of accounting and auditing standards is the Saudi Organization of Certified Public Accountants (SOCPA). The later regulatory body was established based on the Royal Decree No. M/12 dated in 1992 (SOCPA, 2020).

More importantly, in Jul. 2013, the SOCPA board decision approved an IFRS convergence plan and stated that all listed companies other than banks and insurance companies were required to follow IFRS in 2017, and other entities to do the same in 2018. Then, in Mar. 2014, the CMA issued a circular requiring all non-financial companies listed in the Saudi stock market to submit their financial statements in accordance with IFRS in 2017.

For the conversion to IFRS, the SOCPA and CMA have made great efforts to support and assist companies in implementing the IFRS. First, to evaluate the suitability of individual standards to the Saudi financial and business environment, the SOCPA set out a project called "Transition to International Accounting Auditing Standards", which was initiated in 2012 and accomplished in 2016 (SOCPA, 2018). Moreover, to assist the entity in conversion to IFRS, the SOCPA issued a set of applied guidelines to support the conversion process to IFRS and providing training courses about the IFRS from 2014 until 2019. Second, the CMA issued several circulars based on the recommendations and guidelines issued by the SOCPA, to verify that the listed companies

1 For more details: https://cma.org.sa/en/AboutCMA/Pages/AboutCMA.aspx 
are ready to prepare their IFRS annual reports in a time and proper way, and the extent of their full commitment to implement the IFRS conversion plan. These circulars are mostly in the form of required disclosures and, are to be published in the Board of Director's report or/and on the Saudi stock exchange (Tadawul) website. In general, these circulars are contained requirements about the disclosure of conversion to the IFRS.

However, related to the CG regulations, the CMA issued the first CG code in Nov. 2006, and it was mostly guidelines and recommendations. Also, this CG had gone through several amendments as a result of enforcing some articles during the period from 2008 to 2010. Later, a new code of CG was issued in 2017 and has increased mandatory details and articles and provided more clarifications.

\section{Literature Review}

\subsection{CG and its Impacts on Mandatory Disclosure}

Research has investigated many benefits and values that can be gained from adopting a high-quality CG structure. One of these aspects is the impact of CG attributes on corporate disclosure. According to a literature review study conducted by Brown et al. (2011), the results of previous studies show an association between good quality of $\mathrm{CG}$ and higher corporate disclosure levels with stricter regulations' compliance. However, empirical studies have shown mixed results about such impacts.

For example, in European countries, Verriest et al. (2013) investigated the association between CG and disclosure and compliance with IFRS from 223 European companies located in 15 countries studied for 2005. They reported that some companies did not meet the minimum required disclosure. Also, they found that companies with a greater BD independence and more effective $\mathrm{AC}$ tended to provide higher-quality information and comply more fully and less opportunistically when using IFRS. Additionally, they reported that CG had a positive relationship with conservative accounting choices. In Greece, Tasios and Bekiaris (2014) investigated the impact of company size, leverage, profitability, liquidity, audit firm size, ownership dispersion, board independence, and chairman's duality on the mandatory disclosure. Their sample comprised 72 companies studied for 2011. They found an adequate level of average compliance with mandatory disclosure requirements. They reported that the mandatory disclosure was positively associated with company size and liquidity and negatively associated with chairman's duality.

Moreover, In China, Gao and Kling (2012) examined the impact of auditor size, internal CG, and external CG environment on compliance with mandatory disclosure requirement by companies listed in the Shenzhen stock exchange. The study sample comprised 8864 firm-year observations over the period from 2001 to 2007. They found that compliance with mandatory disclosure requirements was influenced by auditor size, internal CG, and external CG environment. Other study in Turkey conducted by Aksu and Espahbodi (2016). They investigated the impact of CG and conversion to IFRS on the intensity and type of transparency and disclosure. The sample consisted of 51 companies from 2003 to 2005. Their study demonstrated the importance of CG, mostly BD attributes, with respect to mandatory disclosure.

From the scale of the Arabian GCC, particularly in Bahrain, the study by Juhmani (2017) investigated the impact of CG attributes on the level of compliance with IFRS disclosures. The sample comprised 41 companies studied for 2010. He reported that the independence of BD and AC, chairman's duality, profitability, auditor size, and industry are positively associated with the level of IFRS disclosure. Another study in Kuwait was conducted by Alfraih (2016) which investigated BD attributes on mandatory compliance with IFRS. The sample comprised 134 non-financial companies in 2010. He found that BD size, gender diversity, multiple directorships, and company size had a positive impact on mandatory disclosure compliance. However, the study reported a negative impact on chairman's duality on mandatory disclosure. On the other hand, Aljifri et al. (2014) investigated the impact of company characteristics on corporate financial disclosures in United Arab Emirates. The sample comprised 153 non-financial companies in 2005. They found that listing status, industry type, and company size had a positive and significant association with the level of disclosure.

Beyond the above studies, intensive studies have investigated the impact of CG on corporate disclosure in general. For instance, Boshnak (2017) investigated the existence of corporate disclosure and its association with corporate characteristics, ownership structure, CG attributes, and culture in GCC. The sample comprised 392 firm year observations during the period between 2010 to 2013 . He found that mandatory disclosure varied between countries. He further explained that factors affecting each type of disclosure are different. He stated that the level of mandatory disclosure is mostly associated with the company size, international ownership, age, government ownership, BD independence, and education. In contrast, it decreased with profitability, institutional ownership, BD size, and chairman's duality.

In the African region, particularly in Libya, Alnabsha et al. (2017) investigated the impact of CG and company attributes on corporate disclosure behavior. The sample consisted of 39 companies considered from 2006 to 2010. They found that the company age, liquidity, listing status, industry, auditor size, AC, and frequency of BD meetings were positively associated with the level of corporate disclosure, while the board independence and size were negatively related to the level of the corporate disclosure. 


\section{2 Research on Disclosure of Conversion to IFRS}

Disclosure about the conversion to IFRS in pre-adoption is essential for a company because it affects investors' perceptions and decisions. This disclosure would be driven by the company's financial and managerial objectives (Iatridis, 2012). Therefore, Verriest et al. (2013) recommend regulators to provide more guidance on how to implement new accounting rules to increase transparency and comparability. Schipper (2005) confirmed that the demand for guidance about the conversion and implementation of IFRS is increased as more countries and companies convert to IFRS.

Therefore, countries attempt to support the conversion process by issuing transition guidance. From this perspective, international institutions and countries issued guidance for conversion to IFRS. For instance, in 2003, the European Securities Regulatory Commission issued a standard called (The Recommendation for Additional Guidance Regarding the Transition to IFRS) in the European Union. Furthermore, Australia is sued a standard called (Disclosing the Impacts of Adopting Australian Equivalents to IFRS) in 2004. Portugal issued a document that obliged companies to disclose the impact of the transition to IFRS in 2005. In KSA, the CMA required listed companies to disclose the plan of transition to IFRS in 2015 and 2016.

Most of these guidelines are mandatory or take the obligatory nature. Thus, companies are required to disclose the implementation of IFRS and material effect in the financial statement. Dunne et al. (2008) demonstrated that such guidance would help solve the biggest implementation problem related to time commitment when converting to IFRS. Moreover, Lopes and Viana (2008) found this disclosure guidance to assist companies in providing comparable, relevant, and understandable disclosure information during the conversion process. However, CG and company characteristics have received attention as they affected the disclosure about the conversion to IFRS (Aksu \& Espahbodi, 2016; Kent \& Stewart, 2008; Miihkinen, 2008). On the other hand, Alotaibi (2017) confirmed the importance of good practices and implementation of accounting standards in a good way because this will lead to effective disclosure and will consequently reflect the quality of CG attributes.

Overall, as the researcher knows, studies that examine companies' disclosure of the implementation of conversion to IFRS in financial statements before the conversion to IFRS are limited. These studies can be categorized into two categories. First are studies that examine the disclosure about the transformation plan in general, and second are studies that focus on measuring compliance with the disclosure requirements for conversion issued by the country's regulatory body. In the first category, for instance, in New Zealand, Stent et al. (2013) investigated the discretionary narrative information in annual reports about the company's responses and attitudes toward adopting IFRS. The sample consisted of 80 companies examined for 2005 to 2008 . They found that the disclosure of narrative information is in low levels, although it had a material impact on financial statements.

The second category is studies investigating conversion disclosure consists of studies focusing on measuring compliance with the disclosure requirements for conversion issued by the country's regulatory body. For instance, in Portugal, Lopes and Viana (2008) examined compliance with the disclosure requirements by Portugal market regulator for conversion to IFRS. They analyzed disclosures of Portuguese companies to determine whether they were in accordance with the objectives of comparability and relevance stated in the requirements of Portugal market regulator. Moreover, they attempted to identify the most problematic areas in the transition to IFRS. The sample comprised 44 companies in the first quarter of 2005 . They found a high level of variability of the disclosure of the transition to IFRS among companies. Moreover, they found that the objectives of Portugal market regulator regarding the disclosed information were achieved. Further, they reported that the recognition of intangibles, the accounting treatment of goodwill, and financial instruments were the primary elements affected by the transition to IFRS.

Kent and Stewart (2008) examined the relationship between CG and CDC according to the Australian standard (Disclosing the Impacts of Adopting Australian Equivalents to IFRS). The sample consisted of 965 non-financial companies studied for 2004. They found a positive relationship between the top management structure, AC, and the quality of the external auditor, and the highest disclosure in the financial reports regarding the conversion to IFRS. In Finland, Miihkinen (2008) examined the extent of the recommended and voluntary disclosures of the conversion to IFRS by Finland companies with that required by the Finland capital market. The focus was on the impact of CG and company attributes on the disclosure of the conversion to IFRS. The sample consisted of 173 companies examined for the two years before the conversion to IFRS in 2005 . He found that the recommended disclosures had higher values than the voluntary disclosures. Further, he reported that the $\mathrm{CG}$, incentives of managers, and company characteristics had a low effect on the recommended disclosure than voluntary disclosure. Additionally, he found that company size and growth, and the independence of BD positively affected the recommended disclosure, but leverage had negative effects.

Furthermore, Bentwood and Lee (2012) attempted to analyze the reconciliation of GAAP into IFRS for 457 Australian companies. They confirmed that companies required more support during conversion to IFRS to reduce the manipulation and management of the benchmark, especially on flexible standards. They reported that 
companies that provided adequate disclosure of the transition plan had fewer material errors in restatement and benchmark management. They also found that the Big4 audit firms and identifying the conversion effects and estimates helped companies lessen the errors of conversion.

\section{Hypothesis Development}

The agency theory proposes that a relationship is created when a person (the principal) engage another person (the agent) to act on his or her behalf, which involves delegating some decision-making authority to the agent (Jensen \& Meckling, 1976). The agency theory has become the dominant theoretical framework employed in the literature to explain the relationship between CG and corporate disclosures (Aksu \& Espahbodi, 2016; Alnabsha et al., 2017; Kent \& Stewart, 2008; Miihkinen, 2008; Rahman \& Hamdan, 2017). The fiduciary duty of the CG refers to the highest standard of care. Thus, CG attributes should play an important role concerning the conversion to IFRS and compliance with disclosure requirements about the IFRS adoption plan. The information asymmetry problems that arise between a manager and shareholders may be reduced through disclosing sufficient information. However, companies are different with respect to their characteristics and CG attributes, thus their effectiveness in disclosing information to mitigates information asymmetry problems might be different.

Accordingly, this study has adopted a framework assuming that CDC is expected to be influenced by the $\mathrm{CG}$ attributes as independent variables- the BD and $\mathrm{AC}$ attributes- while the company characteristics are employed as control variables. However, due to the availability of data, this study focuses on three BD attributes -independence, size, and the number of meetings - and on two AC attributes - size, and the number of meetingsthat expect to influence CDC.

\subsection{Independence of the Board of Directors}

The independence of the BD reflects the proportion of independent members in the BD. Several regulatory initiatives define what is meant by independence and determine the minimum number of independent directors on the board. For example, the OECD (2015) recommends that the BD should consists of at least $50 \%$ to $30 \%$ independent directors for voluntary standard and legal requirements, respectively. It has been assumed that independence of BD enhances the effectiveness of governance of the executives and helps directors to meet their fiduciary duties to the shareholders (Anand, 2008). Also, the independent members boost the monitoring of management, and this is one of the best practices of the CG procedures on dealing with the impact of information asymmetry (Elbadry et al., 2015). Numerous studies found that independence of the BD has a positive impact on the mandatory disclosure (e.g., Boshnak, 2017; Juhmani, 2017; Miihkinen, 2008). They confirm the believe that having more involvement of non-executive directors will promote board independence from management and lead to more compliance with mandatory disclosure.

In contrast, Alnabsha et al. (2017) argued that most independent directors have a lack of actual independence due to the cultural influence, which appointment of independent director relied on social connections rather than individuals' professional competency. Another argument by Annuar (2012) who reported that non-executive directors have lack of time, power and influence, and access to inside information in comparison with executive directors, so their effects with respect to technical affairs of the company are limited. While, other studies did not find any significant impact of independent of BD on corporate disclosure (e.g., Ahmed, 2015; Ettredge et al., 2011; Gao \& Kling, 2012; Kent \& Stewart, 2008). Based on the above arguments, the following hypothesis has been formulated:

H1: There is an association between the proportion of the number of independent members and compliance with the disclosure requirements about conversion to IFRS.

\subsection{Size of the Board of Directors}

The BD size refers to the total number of directors on the company's board, implying that board members having different specializations managerial experience, and reflecting different perspectives of the shareholders who appointed them. Rezaee and Riley (2010) demonstrated that there is no perfect size or general legislation that determines the number of members on board, and most jurisdictions consider that a desirable structure is that provides an appropriate balance between executive and non-executive members. Most jurisdictions impose a minimum number of members on the board as between three and five, and most of them do not determine the maximum, but there are jurisdictions that determine the maximum size as between 15 and 21(OECD, 2019). The impact of the size of BD on board effectiveness has been the subject for debates. From one side, the large size of BD could help the board's monitoring capacity and the availability of a combination of expertise and skills on the board. Various studies found a positive impact between BD size and corporate disclosure (e.g., Ahmed, 2015; Alfraih, 2016; Kent \& Stewart, 2008). Other side of studies argue that the benefits of large size add incremental costs to the decision-making time that relate to large groups. Also, researchers indicate that the large size relates to poor communication and monitoring, which lead to low monitoring of executives which could reduce 
corporate disclosures (Alnabsha et al., 2017; Boshnak, 2017). However, the other studies did not find any significant between BD size and the disclosure (e.g., Gao \& Kling, 2012; Juhmani, 2017). Based on the above arguments the following hypothesis has been formulated:

H2: There is an association between the size of board of directors and compliance with the disclosure requirements about conversion to IFRS.

\subsection{Number of the Board of Directors Meetings}

The number of annual board meetings is used as one of the indicators in referring to the effectiveness of the BD. The frequent meetings of the $\mathrm{BD}$ and its committees are more likely reflecting their involvement and time spent on the company's affair so to perform their duties and monitoring role effectively which would enhance the company's transparency and disclosure (Elbadry et al., 2015). Rezaee and Riley (2010) demonstrated that to present high-quality and transparent annual reporting, the board is required to be active enough to meet their CG duties. The regulations of most countries do not specify BD meeting policies 1 , but they suggest that the best practice should hold regular meetings. Numerous of studies highlight the positive role of the frequently meetings on the BD effectiveness in their monitoring role, thus are resulting in a positive impact on corporate disclosure (Alnabsha et al., 2017; Ettredge et al., 2011; Kent \& Stewart, 2008). However, other studies did not detect any significant influence of meetings of BD (Ahmed, 2015; Chantachaimongkol \& Chen, 2018) on corporate disclosure. Hence, the above discussion led to the formulation of the following hypothesis:

H3: There is an association between the number of board of directors meetings and compliance with the disclosure requirements about conversion to IFRS.

\subsection{Size of the Audit Committee}

The Institute of Internal Auditors (IIA, 2013) recommends that the AC should comprise three and no more than six members, BD nominating committees should select the $\mathrm{AC}$ members, and $\mathrm{AC}$ must have at least one independent member and at least one member of the $\mathrm{AC}$ committee should be financially literate members. However, $\mathrm{AC}$ to be an effective in carrying out its responsibilities it should be having enough members. Some of previous studies emphasised the importance of the size of AC to the effectiveness of the AC. For instance, Li et al. (2008) and Krismiaji (2019) argue that the increase of the AC size should provide adequate resources with different backgrounds, experience, knowledge and skills to perform their functions efficiently and provide better monitoring, which can positively affect the financial reporting quality. In another side, other studies such as Kent and Stewart (2008) have suggest that ACs with fewer members tend to have support from an external consultation comprising professionals and not only based on committee resources, might help AC to focus on performance, especially if the consultation came from Big4 audit firms. While, other studies did not find any significant impact AC size on corporate disclosure (Juhmani, 2017; Sellami \& Fendri, 2017). Thus, this led to the formulation of the following hypothesis:

H4: There is an association between the size of audit committee and compliance with the disclosure requirements about conversion to IFRS.

\subsection{Number of Audit Committee Meetings}

The number of $\mathrm{AC}$ meeting refers to the number of $\mathrm{AC}$ meetings being held annually. According to the IIA (2013) recomendation that the AC should meet at least four times per a year. Number of studies highlight the positive role of the frequently meetings on the $\mathrm{AC}$ effectiveness in their monitoring role, thus are resulting in a positive impact on corporate disclosure. For example, Chantachaimongkol and Chen (2018) demonstrated that the frequency of AC meetings enhances the efficiency of monitoring financial reporting, increases the effectiveness of discussions and effectively enables following issues about corporate disclosure. Kent and Stewart (2008) reported that opportunities to deal with the company's potential problems increase with the frequency of meetings and providing the information that $\mathrm{AC}$ needs is increases with the frequency of meetings which enhances the effectiveness of AC. In contrast, other studies did not found any effect of the number of AC meetings on corporate disclosure (Sellami \& Fendri, 2017). Since the impact of the number of AC meetings on corporate disclosure is arguable, the following hypothesis has been formulated:

H5: There is an association between the number of audit committee meetings and compliance with the disclosure requirements about conversion to IFRS.

\section{Research method}

\subsection{Data collection and sampling}

This study examines Saudi companies' annual reports of 2015 and 2016 as a primary source of data, in terms of the association between CG attributes and CDC, which is mandated by CMA circular No. (16/383/1/7). This

1For more details: https://www.dlapiperintelligence.com/goingglobal/corporate/handbook.pdf 
circular obligates companies to disclose the IFRS conversion plan in the board of directors' reports in 2015 and 2016. The annual report is considered as a legal document that has a formalised, valid, and reliable structure of disclosure (Duriau et al., 2007). In the KSA context, companies are obliged to publish their annual reports on the Saudi stock exchange website (Tadawul). The information on this website is available to all interested parties. Thus, this study relied on the website of Tadawul when collecting the sample data.

The study sample covers all non-financial companies listed on the Saudi stock market. All these companies were required to adopt IFRS in 2017. For this reason, this study excludes companies that did not fit the study objective, such as banks and insurance companies, as they have a different period of conversion to IFRS and a different regulatory body. At the time of the study, there were 131 non-financial companies listed in 2015 and 2016. After excluding companies that did not have a board of directors' reports for 2015 or 2016 or both, the sample consisted of 118 companies in 16 different sectors. Therefore, the final sample size is 236 observations.

\subsection{Dependent Variable}

There are many reasons behind selecting the disclosure of conversion to IFRS rather than the other types of mandatory disclosure. First, the lack of studies investigating this type of disclosure (as per the researcher's knowledge). Second, this kind of disclosure is a rare occurrence in company life. Thus, in the company's interest, the disclosure of sufficient information is a good indicator. Third, adequate preparation for the implementation of IFRS improves the quality of the conversion to IFRS (Weaver, 2014). Based on the last reason, CMA has attempted to verify the companies' readiness to prepare their IFRS annual reports on time and the extent of their commitment to implement the conversion plan. Thus, the CMA issued several circulars that obligated listed companies to disclose the conversion plan in the annual reports. Thus, investigating the impact of BD and AC attributes on this mandatory disclosure could provide important, valuable, and new evidence about the influence of CG structure on corporate disclosure literature.

However, the construction of the disclosure of conversion to IFRS checklist was prepared based on CMA circulars. Further, the checklist was reviewed by two academics; then, the comments were discussed and considered. Additionally, the checklist consisting of 33 items for disclosure of conversion to IFRS was drafted. Later, the 9 items were deleted because they were replicating other items or based on comments of the reviewers. The final modified checklist consisted of 24 items (Appendix 1), and it is categorized into two main groups: The year 2015 (10 items) and the year 2016 (14 items). Also, the present study applied the unweighted approach because it focuses on all financial statement users rather than one particular user group. Thus, each item of disclosure is considered equally important. Further, this study uses binary measurement to measure each item's scores (1) if disclosed and (0) otherwise. When coding the items, the scores are given if the item is found without considering the intensity of the item disclosed.

Reliability and validity of the disclosure checklist: Following the previous corporate disclosure studies (Ahmed, 2015; Tran, 2018), this study employed the most common measures to assess reliability, namely intercoder reliability and internal consistency reliability. The inter-coder reliability result, when compared to two random samples to ensure the coding reliability among coders were similar, and the results of this test did not find any significant difference. Also, the result of Cronbach's alpha coefficient test that used to assess internal consistency shows a value of 0.78 , thus, the internal consistency can be maintained. On another side, for the validity, the checklist has been constructed based on the CMA circulars which have official status. Second, the constructed checklist was reviewed by two academics, then discussed to ensure the final checklist's ability. Finally, the Pearson Correlation test is employed to evaluate the internal consistency validity of the disclosure checklist. The result shows all disclosure checklist categories are highly correlated with total disclosure.

\subsection{Research Model}

This study examines the impact of five independent variables representing CG attributes and four control variables on CDC. A dummy variable of the year was incorporated to consider the effect of the years. Table. 1 provides a summary of the definitions and measurements of the variables. The following main model is developed as follows:

CDCit $=\beta 0+\beta 1$ BDIit $+\beta 2$ BDMit $+\beta 3$ BDSit $+\beta 4$ ACSit $+\beta 5$ ACMit $+\beta 6$ Sizeit $+\beta 7$ Levit $+\beta 8$ Intlit + $\beta 9$ Indit + Yeart $+\varepsilon$ 
Table 1: Definitions and measures of variables

\begin{tabular}{|c|c|}
\hline \\
\hline \multicolumn{2}{|c|}{ Dependent variable } \\
\hline \multirow[t]{2}{*}{$\mathrm{CDC}$} & Compliance with \\
\hline & Conversion to IFRS \\
\hline \multicolumn{2}{|c|}{ Independent variable } \\
\hline BDI & Board Directors Independence \\
\hline BDM & Board Directors Meeting \\
\hline BDS & Board Directors Size \\
\hline $\mathrm{ACM}$ & Audit Committee Meeting \\
\hline $\mathrm{ACS}$ & Audit Committee Size \\
\hline \multicolumn{2}{|c|}{ Control variables } \\
\hline Size & Firm Size \\
\hline Lev & Firm Leverage \\
\hline Intl & International Ownership \\
\hline Ind & Industry Type \\
\hline$\varepsilon$ & Error \\
\hline
\end{tabular}

\section{Measurement}

of The ratio of the total items disclosed by the company to the total items in the checklist

The ratio of independent non-executive directors to the total board directors in the firm

Number of board directors' annual meetings

Number of the board directors' members on the board Number of audit committee annual meetings

Number of the audit committee members on the committee

The natural logarithm of total assets

Total debts divided by total assets

1 if a foreign ownership exists, and 0 otherwise

1 if the company is in the industrial sector, and 0 otherwise The percentage of error in the study

\section{Empirical results}

\subsection{Descriptive statistics}

Table 2 presented the descriptive statistic of the study variables. Panel A presents the descriptive statistics of continuous variables, and Panel B presents the frequencies of the binary variables. The table indicates that the average level of compliance with the disclosure requirements about the conversion to IFRS is 0.72 . This means that $72 \%$ of the disclosure checklist items were disclosed by listed companies. Deeper, the disclosure in 2015 is 0.77 , while it decreases in 2016 to 0.67 . The reduction in the rate of disclosure in 2016 may be due to several reasons. First, the first year (2015) required general information about the IFRS conversion plan, while the second year (2016) required more detailed information on the IFRS conversion plan. Second, the second year involved some difficult type of information like the financial impacts that resulted from the conversion to IFRS, which are requiring the company to complete the adjustment of financial statements before disclosing the IFRS conversion plan. Third, some companies depend on the disclosure they published on the Saudi Stock Exchange (Tadawul) website, and they do not disclose enough information in the financial annual report as required by the CMA. However, when comparing the overall disclosure score of this study to the study conducted by Boshnak (2017) that examined the mandatory disclosure for IASs/IFRSs, the present study results are very closed. Boshnak (2017) reported a disclosure rate value of $73 \%$ in GCC and $71 \%$ in KSA.

Panel A

$\begin{array}{llll}\text { Variables } & \text { Mean } & \text { Median } & \text { Std. Deviation } \\ \text { CDC in 2015 } & 0.777 & 0.800 & 0.230 \\ \text { CDC in 2016 } & 0.677 & 0.715 & 0.224 \\ \text { CDC in Total } & 0.725 & 0.789 & 0.232 \\ \text { BD Size } & 8.35 & 9 & 1.50 \\ \text { BD Independence } & 0.50 & 0.44 & 0.17 \\ \text { BD Meetings } & 5.61 & 5 & 1.62 \\ \text { AC Size } & 3.46 & 3 & 0.69 \\ \text { AC Meetings } & 5.90 & 6 & 1.64 \\ \text { Company Size } & 9.344 & 9.308 & 0.731 \\ \text { Company Leverage } & 0.39 & 0.39 & 0.22\end{array}$

Panel B

Control Variables

International Ownership

Industry Type

Table 2: Descriptive statistics of variables

$\begin{array}{lll}\text { Score } & \text { Freq. } & \% \\ \text { With Intl ownership } & 224 & 94.9 \\ \text { Without Intl ownership } & 12 & 5.1 \\ \text { Ind. Companies } & 138 & 58.5 \\ \text { Non-Ind. Companies } & 98 & 41.5\end{array}$

\subsection{Correlation Analysis}

Multicollinearity arises between the variables when the variables have a high correlation (greater than 0.70 ), this 
will affect the reliability of model estimates (Gujarati \& Porter, 2009). The results in Table 3 of the Pearson correlation matrices show that the highest correlation is 0.54 , that was between the meetings of BD and AC which is in acceptable level. Further, Table 3 shows that frequency of meetings of BD and AC, and the international ownership are significantly and positively correlated with $\mathrm{CDC}$, while the independence of BD and industry type are significantly and negatively correlated with CDC.

Table 3: Pearson Correlation Matrix of all variables

\begin{tabular}{|c|c|c|c|c|c|c|c|c|c|c|}
\hline & CDC & BDI & BDS & BDM & 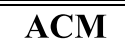 & $\overline{\mathrm{ACS}}$ & $\overline{\text { Size }}$ & Lev & Intl & Ind \\
\hline $\mathrm{CDC}$ & 1 & & & & & & & & & \\
\hline BDI & $-.259 * *$ & 1 & & & & & & & & \\
\hline BDS & -.019 & $-.193 * *$ & 1 & & & & & & & \\
\hline BDM & $.429 * *$ & $-.168 * *$ & .014 & 1 & & & & & & \\
\hline $\mathrm{ACM}$ & $.392 * *$ & $-.132 *$ & .048 & $.539 * *$ & 1 & & & & & \\
\hline ACS & -.013 & $-.164 *$ & $.396 * *$ & $.260 * *$ & $.132 *$ & 1 & & & & \\
\hline Size & -.019 & $-.437 * *$ & $.425 * *$ & $.134 *$ & .094 & $.462 * *$ & 1 & & & \\
\hline Lev & -.040 & $-.269 * *$ & .046 & .003 & .016 & .078 & $.409 * *$ & 1 & & \\
\hline Intl & $.164 *$ & .018 & $-.229 * *$ & .052 & .015 & $-.151 *$ & -.102 & $.201 * *$ & 1 & \\
\hline Ind & $-.180 * *$ & .068 & -.060 & $-.137 *$ & $-.189 * *$ & $-.169 * *$ & -.043 & -.040 & $.196^{* *}$ & 1 \\
\hline
\end{tabular}

$* * *$ indicates $\mathrm{p}<.01, * * \mathrm{p}<.05, * \mathrm{p}<0.10$. Variables: CDC denotes compliance with disclosure about conversion to IFRS; BDI denotes board independence; BDS denotes board size; BDM denotes board meetings; ACS denotes audit committee size; ACM denotes audit committee meetings; Size denotes firm size; Lev denotes leverage; Intl donates international ownership; Ind denotes industry type.

\subsection{Regression Results}

Before employed the OLS multivariate regression technique, the basic assumptions were tested. Normality and linearity of the data are approved, and no problem of autocorrelation between variables (Durbin Watson $=1.95$ ). Also, the VIF and Tolerance are within the acceptable levels, so there is no chance of multicollinearity between the independent variables. Table 4 reports the results for the model examining the impact of five independent variables and four control variables on $\mathrm{CDC}$, with considering the fixed effect of years by including the years as a dummy variable.

Table 4 shows the results, the p-value indicates that the model is statistically significant for explaining the relationship among variables $(\mathrm{F}=13.617, \mathrm{p}<0.000)$. Overall, all variables in the model are explaining $37.7 \%$ of the dependent variable's variance. The adjusted R Square is 34.9 , indicating that $34.9 \%$ of the change in the disclosure score about the conversion to IFRS are explained by the changes in the examined variables. These results are similar to those of Miihkinen (2008) reported a 39\% in Finland, as well as Kent and Stewart, (2008) reported finding of $24 \%$ in Australia.

Table 4: OLS regression results

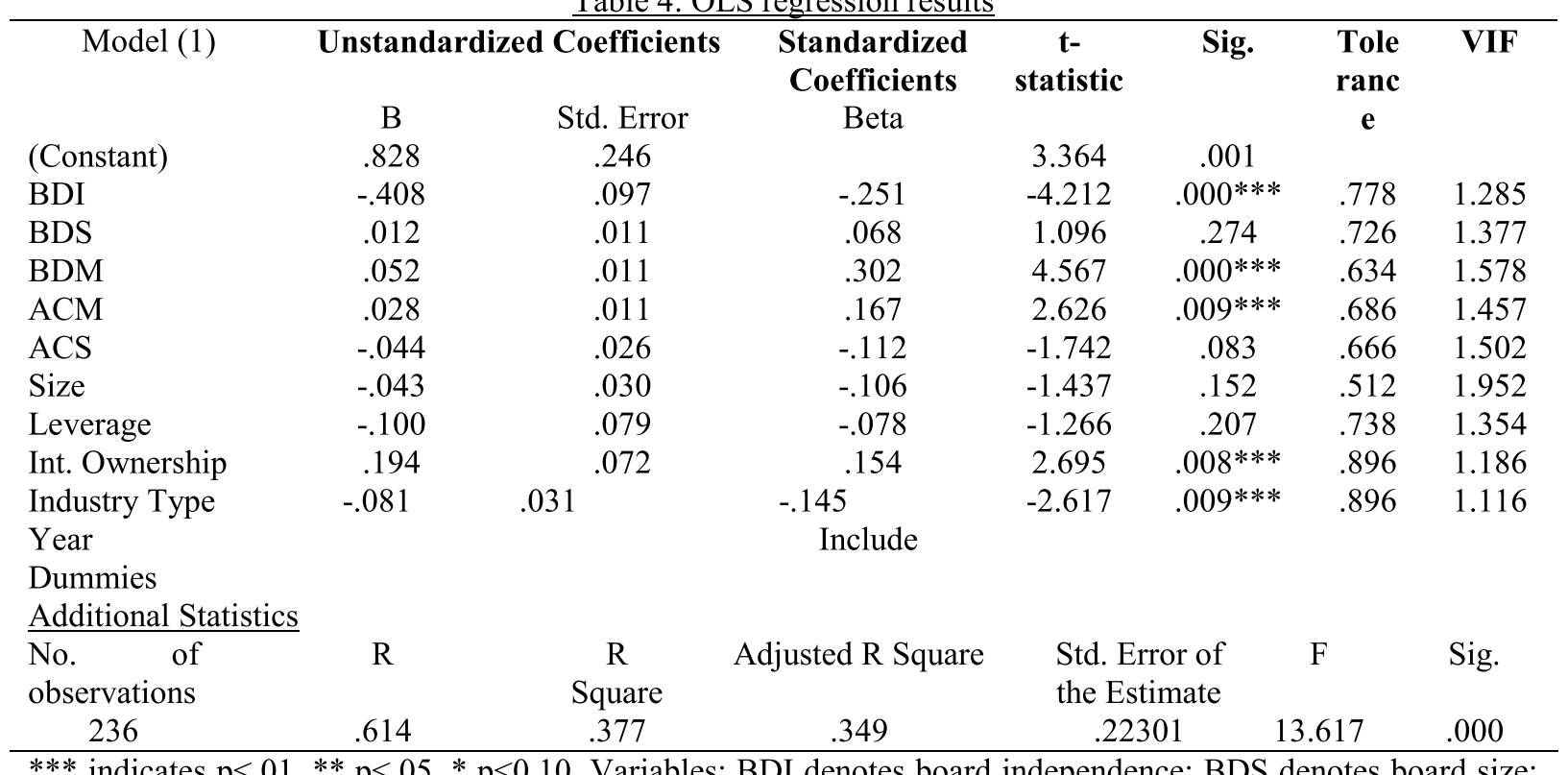

indicates $\mathrm{p}<.01, * * \mathrm{p}<.05, * \mathrm{p}<0.10$. Variables: BDI denotes board independence; BDS denotes board size; denotes firm size; Lev denotes leverage; Intl ownership donates international ownership; Ind denotes industry type; Year denotes 2015 or 2016. 
Generally, the results indicate that the CG variables are associated with the CDC. First, the number of BD and $\mathrm{AC}$ meetings are significantly and positively associated with CDC at the $1 \%$ level. Hence, the hypothesizes (H3) and (H5) are supported. These results are in line with the similar study carried out by Kent and Stewart (2008). The frequent meetings of the board and its committees are more likely reflecting their involvement and time spent on the company's affair so to perform their duties and monitoring role effectively which would enhance the company's transparency and disclosure (Elbadry et al., 2015). So, this results suggest that the involvement of and the time spent by the $\mathrm{BD}$ and $\mathrm{AC}$ are very important to enhance effectiveness of the company CG.

In the other side, the result shows that the board of directors independence (BDI) is significantly and negatively associated with CDC at the $1 \%$ level. Hence, the hypothesis (H1) is supported. This result supports previous studies that reported similar findings (Alnabsha et al., 2017; Barako et al., 2006; Eng \& Mak, 2003). This result might be explained by the suggestion of Annuar (2012) reported that non-executive directors have lack of time, power and influence, and access to inside information in comparison with executive directors, so their effects with respect to technical affairs of the company are limited. So, having executive directors with more knowledge and experience about financial reporting on the company's board of directors would effectively enhance the conversion to IFRS and increase disclosure about this conversion. Another explanation, by Alnabsha et al. (2017) argued that the appointment of independent directors relies on social connections rather than individuals' professional competency. However, the results of the size of BD and AC does not show any statistically significant evidence regarding the association between the size of BD and AC and the CDC. Therefore, the hypothesizes (H2) and (H4) are rejected. Our results are in line with previous studies that found no significant association between corporate disclosure and the BD size (Gao \& Kling, 2012; Juhmani, 2017), and AC size (Juhmani, 2017; Sellami \& Fendri, 2017).

With respect to the control variables, the international ownership (Int. Ownership) is significantly and positively associated with CDC at the $1 \%$ level. This result is in line with the study by Al-Shammari et al. (2008). This confirm that companies with international ownership have more motivation to convert to IFRS, and more compliance to disclose such conversion. On the other hand, the study results that the industry type has a negative and significant relationship with $\mathrm{CDC}$ at the $1 \%$ level. This negative result is consistent with the studies by (e.g., Alfraih, 2016; Barako et al., 2006; Boshnak, 2017). This negative association is explained by Weaver (2014). The later study investigated adoption of IFRS and reported that companies in the industrial sectors are more reluctant to adopt IFRS because of the complexity of their activities when converting to IFRS in comparison with companies working in other sectors and this probably affect the disclosure of the conversion to IFRS by Saudi companies (Weaver, 2014).

However, this study found the company size (Size) did not have any significant influence on CDC. This result of negative influence of company size is confirmed by Ahmed (2015). However, the law requires companies to disclose mandatory disclosure items, thus all companies that want to avoid sanctions should disclose, so the impact of the company size could be slight be (Miihkinen, 2008). Further, the results of this study found the companies' leverage (Leverage) has a negative insignificant relationship with CDC. This result is in line with the similar study carried out by Miihkinen (2008).

\subsection{Additional Analyses}

The study carries out additional analyses to check the robustness of the results in Table 5. First, the re-estimated of the main model by investigating individually each year as follows; the period of 2015, and 2016 represented in model (2), and model (3), respectively. The results reported in models (2) and (3) are generally similar to the main model. The coefficients show the same direction for all variables, and the significance levels are similar for all variables except for the industry type in 2015. Second, conducting the sensitivity analysis for dependent variable by utilized the ordinal ranking into three levels, as suggested by previous studies (Ahmed, 2015; Stent et al., 2013). The results in model (3) are consistent with the main model (1), and thus the study's general conclusions are unchanged, except for slight changes in the significance level for the number of BD meetings, international ownership, and industry type. Third, examined the possible unobserved firm-specific heterogeneity by add two variables of company characteristics represented in model (4). By comparing the results of the main model and model (4), the CG variables are similar in both models, while in the company characteristics the leverage has become significant at a 5\% level. However, these results that are largely unchanged confirm that the study's main findings are not sensitive to potential unobserved company characteristics heterogeneity. 
Table 5: Sensitivity analyses results

\begin{tabular}{|c|c|c|c|c|c|}
\hline Model & $\begin{array}{c}\text { Main model } \\
\text { (1) }\end{array}$ & $\begin{array}{c}\text { Year } 2015 \\
\text { (2) }\end{array}$ & $\begin{array}{c}\text { Year } 2016 \\
\text { (3) }\end{array}$ & $\begin{array}{c}\text { Ordinal } \\
\text { ranking-DC } \\
\text { (3) }\end{array}$ & $\begin{array}{c}\text { Fixed effect } \\
\text { (4) }\end{array}$ \\
\hline \multicolumn{6}{|c|}{$\underline{\text { Corporate Governance Variables }}$} \\
\hline $\begin{array}{l}\text { BDI } \\
\text { BDS } \\
\text { BDM } \\
\text { ACM } \\
\text { ACS }\end{array}$ & $\begin{array}{c}-.408(.000) * * * \\
.012(.274) \\
.052(.000) * * * \\
.028(.009) * * * \\
-.044(.083)\end{array}$ & $\begin{array}{c}-.412(.000) * * * \\
-.005(.734) \\
.028(.025) * * \\
.024(.032) * * \\
-.028(.383)\end{array}$ & $\begin{array}{c}-.258(.028) * * \\
.020(.138) \\
.055(.000) * * * \\
.032(.016) * * \\
-.042(.142)\end{array}$ & $\begin{array}{c}-.784(.000)^{* * *} \\
.018(.463) \\
.060(.014)^{* *} \\
.061(.009)^{* * *} \\
-.087(.117)\end{array}$ & $\begin{array}{c}-.467(.000) * * * \\
.014(.203) \\
.052(.000) * * * \\
.025(.019)^{* *} \\
-.050(.050)\end{array}$ \\
\hline \multicolumn{6}{|l|}{ Control variables } \\
\hline $\begin{array}{l}\text { Size } \\
\text { Leverage }\end{array}$ & $\begin{array}{l}-.045(.152) \\
-.100(.207)\end{array}$ & $\begin{array}{l}.000(.990) \\
-.165(.080)\end{array}$ & $\begin{array}{l}-.042(.060) \\
-.088(.332)\end{array}$ & $\begin{array}{l}-.031(.512) \\
-.291(.091)\end{array}$ & $\begin{array}{c}-.043(.263) \\
-.187(.033)^{* *}\end{array}$ \\
\hline Int. Ownership & $.194(.008) * * *$ & $.262(.001) * * *$ & $.242(.005) * * *$ & $.367(.020)^{* *}$ & $.225(.002) * * *$ \\
\hline Industry Type & $-.081(.009) * * *$ & $-.081(.170)$ & $-.099(.006) * * *$ & $-.126(.045)^{* *}$ & $-.090(.004) * * *$ \\
\hline Year Dummies & Include & Exclude & Exclude & Include & Include \\
\hline Firm dummies & Exclude & Exclude & Exclude & Exclude & Include \\
\hline (Constant) & $.828(.001)$ & $.662(.043)$ & $.779(.021)$ & $1.595(.010)$ & $.749(.008)$ \\
\hline F value & 13.617 & 7.297 & 7.955 & 7.016 & 11.960 \\
\hline Sig & .000 & .000 & .000 & .000 & .000 \\
\hline Adjusted R2 & .349 & .326 & .339 & .197 & .359 \\
\hline No. & 236 & 118 & 118 & 236 & 236 \\
\hline
\end{tabular}

observations

$* * *$ indicates $\mathrm{p}<.01,{ }^{* *} \mathrm{p}<.05, * \mathrm{p}<0.10$. Variables: BDI denotes board independence; BDS denotes board size; BDM denotes board meetings; ACS denotes audit committee size; ACM denotes audit committee meetings; Size denotes firm size; Lev denotes leverage; ; Intl ownership donates international ownership; Ind denotes industry type; Year denotes 2015 or 2016; Firm dummies denote the ratio of return on assets and the ratio of return on equity.

\section{Conclusion}

This study examined the impact of the CG attributes on CDC imposed by the CMA in the Saudi stock market. The empirical evidence of the regression models indicates that there is a significant and positive relationship between $\mathrm{CDC}$ and the number of $\mathrm{BD}$ and $\mathrm{AC}$ meetings and international. This result suggests that the time devoted by members to the company is very important for enhancing the effectiveness of CG practices in Saudi companies, and the international association of the company in the Saudi market help in importing international practices. However, the negative association between the independence of the BD and CDC is more likely reflecting the environmental practice of BD independence in Saudi companies.

The results have a number of limitations. First, the study covers only non-financial listed companies in the period from 2015 to 2016 in the Saudi stock market, making it difficult to generalize the results to all companies in the KSA. Second, this study focuses on only one disclosure mean, which is companies annual reports, without any consideration of other different means though which companies may publish information pertaining to the conversion to IFRS such as websites or other type of media. Third, the results of this study are subject to the limitations known about the content analysis approach, especially coding the items in the checklist.

This study contributes to our understanding of CG and disclosure, especially relating to the conversion to IFRS, in several ways. First, it provides additional evidence about the impact of CG attributes on corporate disclosures, as the literature available on this topic is limited, especially pertaining to developing countries. Second, the results of this study could help us to evaluate the efforts taken by Saudi companies to convert to IFRS. Therefore, regulators and academics could benefit from the results of this study either in terms of the evaluation of compliance with disclosure requirements or in terms of the assessment of the effectiveness of a company's CG structure on mandatory disclosure. Finally, the findings of this study could be beneficial for countries that are planning to adopt IFRS as much as this research would highlight those factors that are effective and efficient in implementing IFRS.

The results of this study recommend enhancing the effectiveness of CG among KSA non-financial companies, especially with respect to appointing independent members in BD. Further, the CMA need to improve the degree of identification and clarification in their circulars as to avoid the problems of narrative disclosures that make determining the disclosure quantity under the board judgment. Finally, the results recommend regulators and enforcement bodies to support companies by providing clear guidelines, enhancing 
the awareness of the benefits of IFRS conversion, improving the knowledge about IFRS, and taking into consideration other factors that influence the effectiveness of the conversion to IFRS. Further research on compliance with the disclosure requirements is needed in the literature, especially in developing countries. Finally, the results of this study confirm the effectiveness of CG's influence on compliance with the disclosure requirements, but adds further interesting areas for further research such as the quality of independence within the KSA companies, and the role of the international association of the company in accelerating the adoption of IFRS.

\section{References}

Ahmed, H. (2015). The Relationship Between Corporate Governance And Environmental Disclosure: UK Evidence. In $\mathrm{PhD}$ thesis unpublished, Durham University.

Aksu, M., \& Espahbodi, H. (2016). The Impact of IFRS Adoption and Corporate Governance Principles on Transparency and Disclosure: The Case of Borsa Istanbul. Emerging Markets Finance and Trade, 52(4), 1013-1028. https://doi.org/10.1080/1540496X.2014.998570

Al-Shammari, B., Brown, P., \& Tarca, A. (2008). An investigation of compliance with international accounting standards by listed companies in the Gulf Co-Operation Council member states. International Journal of Accounting, 43(4), 425-447. https://doi.org/10.1016/j.intacc.2008.09.003

Alfraih, M. (2016). The effectiveness of board of directors' characteristics in mandatory disclosure compliance. Journal of Financial Regulation and Compliance, 24(2), 154-176.

Aljifri, K., Alzarouni, A., Ng, C., \& Tahir, M. I. (2014). The association between firm characteristics and corporate financial disclosures: evidence from UAE companies. The International Journal of Business and Finance Research, 8(2), 101-124.

Alnabsha, A., Abdou, H. A., Ntim, C. G., \& Elamer, A. A. (2017). Corporate boards, ownership structures and corporate disclosures : Evidence from a developing country. Journal of Applied Accounting Research, 19(1), 20-41. https://doi.org/10.1108/JAAR-01-2016-0001

Alotaibi, A. (2017). An empirical investigation of corporate governance practices in the Kingdom of Saudi Arabia. Journal of the North for Humanities, 4(2), 185-199. https://doi.org/10.12816/0052875

Anand, S. (2008). Good Corporate Governance: An Introduction. In Essentials of Corporate Governance (pp. 73-90). Wiley. https://doi.org/10.1002/9781118385210.ch6

Annuar, H. A. (2012). Are there barriers to independent non-executive directors' effectiveness in performing their roles? International Journal of Commerce and Management, 22(4), 258-271. https://doi.org/10.1108/10569211211284476

Ashfaq, K., \& Rui, Z. (2019). The effect of board and audit committee effectiveness on internal control disclosure under different regulatory environments in South Asia. Journal of Financial Reporting and Accounting, 17(2), 170-200. https://doi.org/10.1108/JFRA-09-2017-0086

Ballas, A., \& Tzovas, C. (2010). An investigation of greek firms' compliance to IFRS mandatory disclosure requirements. International Journal of Managerial and Financial Accounting, 2(1), $40-62$. https://doi.org/10.4018/978-1-4666-6268-1.ch045

Barako, D. G., Hancock, P., \& Izan, H. Y. (2006). Corporate Disclosure by Kenyan Companies. Corporate Governance: An International Review, 14(2), 107-125.

Bentwood, S., \& Lee, P. (2012). Benchmark Management During Australia's Transition to International Accounting Standards. Abacus, 48(1), 59-85. https://doi.org/10.1111/j.1467-6281.2012.00357.x

Boshnak, H. (2017). Mandatory and voluntary disclosures in GCC listed firms. In PhD thesis unpublished, University of the West of England (Issues 1-520).

Brown, P., Beekes, W., \& Verhoeven, P. (2011). Corporate governance, accounting and finance: A review. Accounting and Finance, 51(1), 96-172. https://doi.org/10.1111/j.1467-629X.2010.00385.x

Chantachaimongkol, N., \& Chen, S. (2018). The effects of board compositions and audit committee characteristics on information disclosure practices: A case of Singapore. Asian Journal of Finance and Accounting, 10(1), 407-427. https://doi.org/10.5296/ajfa.v10i1.13261

Chen, Y., \& Rezaee, Z. (2012). The role of corporate governance in convergence with IFRS: evidence from China. International Journal of Accounting \& Information Management, 20(2), 1-171-188.

Dunne, T., Finningham, G., Gwen, H., Power, D., Fifield, S., Fox, A., Helliar, C., \& Veneziani, M. (2008). The implementation of IFRS in the UK, Italy and Ireland (Issue January).

Duriau, V., Reger, R., \& Pfarrer, M. (2007). A content analysis of the content analysis literature in organization studies: research themes, data sources, and methodological refinements. Organizational Research Methods, 10(1), 5-34. https://doi.org/10.1177/1094428106289252

Elbadry, A., Gounopoulos, D., \& Skinner, F. (2015). Governance quality and information asymmetry. Financial Markets, Institutions and Instruments, 24(2-3), 127-157. https://doi.org/10.1111/fmii.12026

Eng, L. L., \& Mak, Y. T. (2003). Corporate governance and voluntary disclosure. Journal of Accounting and 
Public Policy, 22(4), 325-345. https://doi.org/10.1016/S0278-4254(03)00037-1

Ettredge, M., Johnstone, K., Stone, M., \& Wang, Q. (2011). The effects of firm size, corporate governance quality, and bad news on disclosure compliance. Review of Accounting Studies889-866, (4)16, . https://doi.org/10.1007/s11142-011-9153-8

Fernandes, S., \& Louren ç, I. (2018). Determinants of compliance with mandatory disclosure: Research evidence. Corporate Ownership and Control, 15(2), 91-98. https://doi.org/10.22495/cocv15i2art8

Gao, L., \& Kling, G. (2012). The impact of corporate governance and external audit on compliance to mandatory disclosure requirements in China. Journal of International Accounting, Auditing and Taxation, 21(1), 17-31. https://doi.org/10.1016/j.intaccaudtax.2012.01.002

Gujarati, D., \& Porter, D. (2009). Basic econometrics. In Introductory Econometrics: A Practical Approach. Tata McGraw-Hill Education.

Healy, P. M., \& Palepu, K. G. (2001). Information asymmetry, corporate disclosure, and the capital markets: A review of the empirical disclosure literature. Journal of Accounting and Economics, 31(1-3), 405-440. https://doi.org/10.1016/S0165-4101(01)00018-0

Iatridis, G. (2012). Voluntary IFRS disclosures evidence from the transition from UK GAAP to IFRSs. Managerial Auditing Journal, 27(6), 573-597.

Jensen, C., \& Meckling, H. (1976). Theory of the firm: Managerial behavior, agency costs and ownership structure. Journal of Financial Economics, 3(4), 305-360.

Juhmani, O. (2017). Corporate governance and the level of Bahraini corporate compliance with IFRS disclosure. Journal of Applied Accounting Research, 18(1), 22-41. https://doi.org/10.1108/JAAR-05-2015-0045

Kent, P., \& Stewart, J. (2008). Corporate governance and disclosures on the transition to International Financial Reporting Standards. Accounting and Finance, 48(4), 649-671. https://doi.org/10.1111/j.1467629X.2007.00257.x

Krismiaji, T. (2019). Corporate governance and firm's compliance on disclosure of International Financial Reporting Standards-Indonesian evidence. International Journal of Accounting, Finance and Risk Management, 4(1), 24. https://doi.org/10.11648/j.ijafrm.20190401.13

Li, J., Pike, R., \& Haniffa, R. (2008). Intellectual capital disclosure and corporate governance structure in UK firms. Accounting and Business Research, 38(2), 137-159.

Lopes, P., \& Viana, R. (2008). The transition to IFRS: disclosures by Portuguese listed companies. Universidade Do Porto, Faculdade de Economia Do Porto, No. 285.

Miihkinen, A. (2008). Efficiency of authoritative disclosure recommendations: Evidence from IFRS transition disclosure in Finland. Journal of Financial Regulation and Compliance, 16(4), 384-413. https://doi.org/10.1108/13581980810918431

OECD. (2015). G20/OECD Principles of Corporate Governance. http://dx.doi.org/10.1787/9789264236882-en

OECD. (2019). OECD Corporate Governance Factbook 2019. OECD, 1-184. https://www.oecd.org/daf/ca/Corporate-GovernanceFactbook.pdf\%0Ahttp://www.oecd.org/daf/ca/Corporate-Governance-Factbook.pdf

Rahman, A., \& Hamdan, M. (2017). The extent of compliance with FRS 101 standard: Malaysian evidence. Journal of Applied Accounting Research, 18(Unit 071), 87-115. https://doi.org/10.1108/JAAR-10-20130078

Rezaee, Z., \& Riley, R. (2010). Board of directors' oversight responsibility. In Financial Statement Fraud and Detection (2nd ed., pp. 138-156). John Wiley \& Sons, Inc. https://doi.org/10.1002/9781119198307.ch7

SAMA. (2015). Historical preview. SAMA. https://doi.org/10.1007/978-3-319-24639-0_1

Schipper, K. (2005). The introduction of International Accounting Standards in Europe: Implications for international convergence. European Accounting Review, 14(1), 101-126. https://doi.org/10.1080/0963818042000338013

Sellami, Y., \& Fendri, H. (2017). The effect of audit committee characteristics on compliance with IFRS for related party disclosures: Evidence from South Africa. Managerial Auditing Journal, 32(6), 603-626. https://doi.org/10.1108/MAJ-06-2016-1395

SOCPA. (2018). The transformation to international tandards (accounting and auditing). https://socpa.org.sa/SOCPA/files/13/13479bc7-12a5-4b0d-8999-70c73e8ec232.pdf

SOCPA. (2020). SOCPA - About us. SOCPA. https://socpa.org.sa/Socpa/About-Socpa/About-us.aspx

Stent, W., Bradbury, M., \& Hooks, J. (2013). What firms' discretionary narrative disclosures reveal about the adoption of international financial reporting standards. Australian Accounting Review, 23(3), $252-263$. https://doi.org/10.1111/auar.12002

Tasios, S., \& Bekiaris, M. (2014). Mandatory disclosures and firm characteristics: Evidence from the Athens Stock Exchange. International Journal of Managerial and Financial Accounting, 6(4), 303-321. https://doi.org/10.1504/IJMFA.2014.066401

The Institute of Internal Auditors (IIA). (2013). Model Audit Committee Charter. In IIA (Issue May). 
https://global.theiia.org/standards-guidance/Public

Documents/MODEL AUDIT COMMITTEE CHARTER.pdf

Tran, T. (2018). Institutional Environment, Corporate Governance and Corporate Social Responsibility Disclosure: A Comparative Study of Southeast Asian Countries. In The University of Huddersfield Business School (Issue University of Huddersfield, UK). http://eprints.hud.ac.uk/id/eprint/34530/1/Thi Thao Mi Tran FINAL THESIS.PDF

Verriest, A., Gaeremynck, A., \& Thornton, D. (2013). The impact of corporate governance on IFRS adoption choices. European Accounting Review, 22(1), 39-77. https://doi.org/10.1080/09638180.2011.644699

Weaver, L. (2014). Managing the transition to IFRS-based financial reporting : a practical guide to planning and implementing a transition to IFRS or national GAAP which is based on, or converged with, IFRS. In John Wiley \& Sons. Wiley. https://doi.org/10.1017/CBO9781107415324.004

\section{Appendix 1}

Appendix 1: The checklist of the disclosure of conversion to IFRS

\section{No. Item}

2015

1 Is there an introduction about the transition to IFRS?

2 Does the company affirm its commitment to the transition to IFRS?

3 Does the company disclose its plan for the implementation of IFRS?

$4 \quad$ Does the company disclose that the transition plan done before the end of 2015?

$5 \quad$ Is there a description of the company plan for the transition to IFRS?

$6 \quad$ Is there a discussion of the implementation phases?

$7 \quad$ Does the plane determine a time for the transition to IFRS?

8 Does the company disclose that it will be preparing an internal financial statement according to IFRS for 2016 as suggested?

9 Does the company disclose the differences between the rules under IFRS and Saudi standards?

10 Does the company disclose whether it is ready to apply IFRS?

Is the IFRS transition plan disclosed in $2016 ?$

Does the company discuss its plan for the transition to IFRS in 2016 ?

Does the plan provide details about the target date to approve the accounting policies?

Is there information about what is accomplished in the plan for a transition during 2015 ?

Does the company describe the nature of consultation about IFRS adoption it received?

Does the company describe the background of the provider of the consultation about IFRS adoption it received?

17 Does the company nominate an internal team responsible for the IFRS transition plan?

18 Does the company discuss whether there is or (no) any difficulty it is facing in the IFRS transition process?

19 Does the company affirm that the accounting policies necessary for preparing IFRS financial statements had been approved?

20 Does the company provide a view about financial statements under IFRS?

21 Does the company disclose the periods over which such IFRS financial statements had been prepared?

22 Does the company disclose the significant effects resulting from implementing the IFRS, or disclose there are no significant effects?

23 Does the company disclose any quantitative information that affects reported values resulting from implementing the IFRS?

24 Does the company disclose its readiness to prepare its IFRS financial statements for the 2017 first quarter within the applicable regulatory period? 